\title{
PENGARUH PROFESIONALITAS, KETAATAN PADA KODE ETIK, DAN PENGALAMAN AUDITOR TERHADAP PENENTUAN TINGKAT MATERIALITAS
}

\author{
Robinson \\ Universitas Bengkulu \\ (robin76kph@gmail.com)
}

\begin{abstract}
The purpose of this research is the first, provide empirical evidence of the influence of professionalism auditor against consideration the level of materiality, adherence to a code of ethics to the level of materiality considerations, the level of experience of the auditor's consideration of materiality, and provide empirical evidence of the influence of auditor professionalism, adherence to a code of ethics, and experience of the auditor on consideration of materiality levels. The results showed that: 1) Professionalism Auditor (X1) had no significant effect on the Consideration of Materiality level, which is indicated by a significance value of $0.154 ; 2)$ Adherence to the Code of Ethics (X2) has a significant influence on consideration Materiality level, which indicated by a significance value of 0.008 ; 3) experience Auditor (X3) have no significant influence on consideration Materiality level, indicated by a significance value of 0.819, and 4) Auditor professionalism, adherence to the Code of Ethics and Auditor experience together has influence consideration of Materiality significant level, which is indicated by the significant value of 0.000 .
\end{abstract}

Keywords: Professionalism, Code of Ethics, Experience, Materiality Levels

\section{A. Pendahuluan}

Audit yang dilakukan pada sektor publik berbeda dengan yang dilakukan pada sektor swasta. Latar belakang institusional dan hukum yang berbeda yang membedakan audit sektor publik dengan sektor swasta, dimana audit sektor publik mempunyai prosedur dan 
tanggung jawab yang berbeda serta peran yang lebih luas dibandingkan audit sektor swasta (Jones. R,1996:205: Rubin, 1998: 129) dalam Wilopo (2001:27). Hal ini dapat diketahui bahwa auditor pemerintah dalam melaksanakan tugasnya tidak hanya memeriksa dan menilai kewajaran laporan keuangan sektor publik, tetapi juga menilai ketaatan aparatur pemerintah terhadap undang-undang dan peraturan yang berlaku. Disamping itu juga memeriksa dan menilai sifat ekonomis, efisiensi dan efektifitas dari semua pekerjaan dan pelayanan yang dilakukan oleh pemerintah. Dengan demikian, bila kualitas audit sektor publik rendah, maka akan mengakibatkan risiko tuntutan terhadap pejabat pemerintah (Elder, 1997) dan akan muncul kecurangan, korupsi, kolusi seperti yang terjadi di Indonesia sampai saat ini (Wilopo 2001:28). Pemeriksaan Badan Pemeriksa Keuangan Republik Indonesia (BPK-RI) terhadap semua Laporan Keuangan Pemerintah Pusat (LKPP) maupun Laporan Keuangan Pemerintah Daerah (LKPD) hanya pada tahap pemberian opini akuntan, artinya bahwa apakah laporan keuangan disusun sesuai Standar Akuntansi Pemerintahan (SAP) (PP No.71 Tahun 2010), bukan pada kinerja keuangan. Oleh sebab itu harus hati-hati di dalam memaknai sebuah opini akuntan bukan opini kinerja keuangan, kadang hal ini menjadi sebuah informasi yang 'terdistorsi' antara opini akuntan terbaik dengan opini kinerja keuangan terbaik.

Masyarakat pada umumnya berpandangan opini wajar tanpa pengecualian (WTP) menggambarkan kondisi tata kelola keuangan entitas yang mendapatkan bersifat 'bebas korupsi'. Ketika suatu entitas mendapat opini WTP, dan kemudian terjadi kasus korupsi di entitas tersebut, masyarakat meragukan pemberian opini WTP tersebut. Dikalangan pejabat pemerintah pun berbeda-beda di dalam memandang opini WTP yang diberikan BPK kepada entitas terhadap laporan keuangan. Banyak mempertanyakan kenapa suatu entitas tertentu mendapat opini WTP, pada hal kinerjanya buruk. Entitas di pemerintahan yang menyatakan bahwa jika instansinya mendapat opini WTP, maka bebas dari praktek korupsi, kolusi dan nepotisme (KKN). Walau ada perbedaan persepsi mengenai opini WTP, tetapi wajar saja jika entitas yang diperiksa memasang target untuk meraih opini WTP dalam laporan keuangan. Opini WTP memang bukanlah segala-galanya dalam menciptakan aparatur yang bersih. Namun opini WTP merupakan salah satu indikatornya. Laporan keuangan entitas bisa dipertanggungjawabkan sesuai dengan SAP yang berpegangan 
pada prinsip akuntabilitas dan transparansi (Warta BPK).

Dalam Standar Pemeriksaan Keuangan Negara memuat persyaratan profesional pemeriksa, mutu pelaksanaan pemeriksaan, dan persyaratan laporan pemeriksaan yang profesional. Pelaksanaan pemeriksaan yang didasarkan pada standar pemeriksaan akan meningkatkan kredibilitas informasi yang dilaporkan atau diperoleh dari entitas yang diperiksa melalui pengumpulan dan pungujian bukti secara obyektif. Profesionalisme juga menjadi syarat utama bagi para auditor eksternal. Sebab dengan profesionalisme yang tinggi kebebasan auditor akan semakin terjamin. Untuk menjalankan perannya yang menuntut tanggung jawab yang semakin luas, auditor eksternal harus memiliki wawasan yang luas tentang kompleksitas organisasi modern. Gambaran profesionalisme seorang auditor menurut Hall (1968) dalam Herawati dan Susanto, (2009) tercermin dalam lima hal yaitu : pengabdian pada profesi, kewajiban sosial, kemandirian, kepercayaan terhadap peraturan profesi dan hubungan dengan rekan seprofesi.

Ketika manajemen atau subyek audit menawarkan sebuah imbalan atau tekanan kepada auditor untuk menghasilkan laporan audit yang diinginkan oleh manajemen maka menjadi dilema etika. Dilema etis dalam setting auditing terjadi ketika auditor dan auditee tidak sepakat terhadap beberapa aspek fungsi dan tujuan pemeriksaan. Auditee dapat mempengaruhi proses audit yang dilakukan auditor, yaitu dengan menekan auditor melakukan tindakan yang melanggar standar pemeriksaan. Dalam hal ini auditor dihadapkan pada pilihan-pilihan keputusan yang saling bertentangan terkait dengan aktivitas pemeriksaannya. Merebaknya "malpraktik bisnis" dan kurangnya independensi menyebabkan kepercayaan para pengguna laporan auditan terhadap akuntan menjadi menurun. Ketika independensi dan objektivitas terabaikan perdagangan opini auditor menjadi hal yang "wajar" (Anni, 2004).

Untuk dapat mencapai mutu dan kualitas yang baik tentunya hal yang dipertimbangkan salah satunya adalah tingkat materialitas. Tingkat materialitas yang ditetapkan oleh auditor mempunyai peranan terhadap hasil pemeriksaan. Penetapan materialitas membantu auditor merencanakan pengumpulan bahan bukti yang cukup. Jika auditor menetapkan jumlah yang rendah, maka akan lebih banyak bahan bukti yang harus dikumpulkan.

Pertimbangan auditor tentang materialitas adalah suatu masalah 
kebijakan profesional dan dipengaruhi oleh persepsi auditor tentang kebutuhan yang beralasan dari laporan keuangan. Tingkat materialitas suatu laporan keuangan tidak akan sama, tergantung pada ukuran laporan keuangan tersebut. Selain itu tingkat materialitas tergantung pada dua aspek yaitu aspek kondisional dan aspek situasional. Materialitas pada tingkat laporan keuangan adalah besarnya keseluruhan salah saji minimum dalam suatu laporan keuangan yang cukup penting sehingga membuat laporan keuangan menjadi tidak disajikan secara wajar sesuai dengan prinsip-prinsip akuntansi yang berlaku umum. Dalam konteks ini, salah saji bisa diakibatkan oleh penerapan akuntansi secara keliru, tidak sesuai dengan fakta atau karena hilangnya informasi penting (Haryono, 2001 dalam Martiyani, 2010:20).

Penelitian ini dimotivasi karena masih banyaknya pemegang kepentingan yang mempertanyakan hasil audit yang membuat Opini pada Laporan Hasil Pemeriksaan BPK. Dimana selama ini banyak entitas Pemerintah mendapatkan Opini Wajar Tanpa Pengecualian namun masih banyak ditemukannya pelanggaran terhadap peraturan perundang-undangan. Banyak kasus korupsi terhadap entitas yang mendapatkan Opini wajar tanpa pengecualian tersebut.

Berdasarkan pokok permasalahan yang telah dirumuskan dalam rumusan masalah, maka tujuan dari penelitian adalah memberikan bukti empiris:

1) Pengaruh profesionalisme auditor terhadap pertimbangan tingkat materialitas.

2) Pengaruh ketaatan terhadap kode etik terhadap pertimbangan tingkat materialitas.

3) Pengaruh pengalaman auditor terhadap pertimbangan tingkat materialitas.

4) Pengaruh profesionalisme auditor, ketaatan terhadap kode etik, dan pengalaman auditor secara simultan terhadap pertimbangan tingkat materialitas.

\section{B. Landasan Teori}

1) Materialitas

Materialitas adalah besarnya nilai yang dihilangkan atau salah saji informasi akuntansi, dilihat dari keadaan yang 
melingkupinya, yang mungkin dapat mengakibatkan perubahan pengaruh terhadap pertimbangan orang yang meletakkan kepercayaan atas informasi tersebut karena adanya penghilangan atau salah saji tersebut (Sukrisno 1996 dalam Yanuar 2008:18). Materialitas adalah besarnya informasi akuntansi yang apa bila terjadi penghilangan atau salah saji, dilihat dari keadaan yang melingkupinya, mungkin dapat mengubah atau mempengaruhi pertimbangan orang yang meletakkan kepercayaan atas informasi tersebut. Definisi materialitas tersebut mengakui pertimbangan materialitas dilakukan dengan memperhitungkan keadaan yang melingkupi dan perlu melibatkan baik pertimbangan kuantitatif maupun kualitatif. Keadaan yang melingkupi yang harus dipertimbangkan pemeriksa dalam menetapkan materialitas di antaranya adalah sifat dan jumlah pos dalam laporan keuangan yang diperiksa. Sebagai contoh, suatu jumlah yang material bagi laporan keuangan suatu entitas mungkin tidak material bagi laporan keuangan entitas lain dengan ukuran dan sifat yang berbeda. Begitu juga, jumlah yang material bagi laporan keuangan entitas tertentu kemungkinan berubah dari satu periode ke periode yang lain.

Pertimbangan pemeriksa tentang materialitas merupakan pertimbangan yang bersifat professional dan dipengaruhi oleh persepsi yang wajar tentang keandalan dan kepercayaan atas laporan keuangan yang diperiksa. Materialitas mengandung unsur subjektivitas tergantung pada sudut pandang, waktu, dan kondisi pihak yang berkepentingan. Namun, penilaian subjektivitas yang sama dari banyak pihak dapat mengarah pada suatu objektivitas.

Konsep materialitas dapat dikelompokkan menjadi (keputusan BPK No.05/k/I- XIII.2/5/2008):

a) Materialitas kuantitatif; materialitas yang menggunakan ukuran kuantitatif tertentu seperti nilai uang, jumlah waktu, frekuensi maupun jumlah unit.

b) Materialitas kualitatif; materialitas yang menggunakan ukuran kualitatif yang lebih ditentukan pada pertimbangan professional. Pertimbangan professional tersebut didasarkan pada cara pandang, pengetahuan, dan pengalaman pada situasi dan kondisi tertentu.

Dalam menentukan materialitas, tidak terdapat kriteria yang baku, tetapi ada faktor yang harus dipertimbangkan pemeriksa dalam menentukan materialitas, yaitu (keputusan BPK No.05/k/I- 
XIII.2/5/2008):

a) Tingkat kepentingan para pihak terkait terhadap objek yang diperiksa, misalnya pada objek laporan keuangan pemerintah, pengguna laporan keuangan memiliki kepentingan yang tinggi terhadap masalah legalitas dan ketaatan pada ketentuan yang berlaku.

b) Batasan materialitas untuk penugasan pemeriksaan, misalnya batasan materialitas pemeriksaan laporan keuangan pemerintah pusat cenderung konservatif karena sektor publik lebih mementingkan pengujian terhadap legalitas, ketaatan terhadap ketentuan yang berlaku.

\section{2) Profesionalisme Auditor}

Dalam penelitian ini konsep profesionalisme yang digunakan adalah konsep untuk mengukur bagaimana para profesional memandang profesi mereka yang tercermin dalam sikap dan perilaku mereka. Dengan anggapan bahwa sikap dan perilaku mempunyai hubungan timbal balik. Perilaku profesionalisme merupakan cermin dari sikap profesionalisme, demikian pula sebaliknya sikap profesional tercermin dari perilaku yang profesional.

Hall (Syahrir 2002 : 7) mengembangkan konsep profesionalisme dari level individual yang digunakan untuk profesionalisme eksternal auditor, meliputi lima dimensi:

a) Pengabdian pada profesi (dedication), yang tercermin dalam dedikasi profesional melalui penggunaan pengetahuan dan kecakapan yang dimiliki. Sikap ini adalah ekspresi dari penyerahandiri secara total terhadap pekerjaan. Pekerjaan didefinisikan sebagai tujuan hidup dan bukan sekadar sebagai alat untuk mencapai tujuan. Penyerahan diri secara total merupakan komitmen pribadi, dan sebagai kompensasi utama yang diharapkan adalah kepuasan rohaniah dan kemudian kepuasan material.

b) Kewajiban sosial (Social obligation), yaitu pandangan tentang pentingnya peran profesi serta manfaat yang diperoleh baik oleh masyarakat ataupun oleh profesional karena adanya pekerjaan tersebut.

c) Kemandirian (autonomy demands), yaitu suatu pandangan bahwa seorang profesional harus mampu membuat keputusan sendiri tanpa tekanan dari pihak yang lain. 
d) Keyakinan terhadap peraturan profesi (belief in self-regulation), yaitu suatu keyakinan bahwa yang berwenang untuk menilai pekerjaan profesional adalah rekan sesama profesi, dan bukan pihak luar yang tidak mempunyai kompetensi dalam bidang ilmu dan pekerjaan mereka.

e) Hubungan dengan sesama profesi (professional community affiliation), berarti menggunakan ikatan profesi sebagai acuan, termasuk organisasi formal dan kelompok-kelompok kolega informal sebagai sumber ide utama pekerjaan. Melalui ikatan profesi ini para profesional membangun kesadaran profesinya.

Dalam Standar Pemeriksaan Keuangan Negara sesuai Peraturan BPK-RI No.1 Tahun 2007 pada pernyataan standar umum pertama menyatakan Pemeriksa secara kolektif harus memiliki kecakapan profesional yang memadai untuk melaksanakan tugas pemeriksaan. Dengan pernyataan Standar ini semua organisasi pemeriksa bertanggung jawab untuk memastikan bahwa setiap pemeriksaan dilaksanakan oleh pemeriksa yang secara kolektif memiliki pengetahuan, keahlian, dan pengalaman yang dibutuhkan untuk melaksanakan tugas tersebut. Standar umum kedua menyatakan dalam semua hal yang berkaitan dengan pekerjaan pemeriksaan, organisasi pemeriksa dan pemeriksa, harus bebas dalam sikap mental dan penampilan dari gangguan pribadi, ekstern, dan organisasi yang dapat mempengaruhi independensinya. Standar umum ketiga menyatakan dalam pelaksanaan pemeriksaan serta penyusunan laporan hasil pemeriksaan, pemeriksa wajib menggunakan kemahiran profesionalnya secara cermat dan seksama. Standar umum keempat menyatakan bahwa setiap organisasi pemeriksa yang melaksanakan pemeriksaan berdasarkan Standar Pemeriksaan harus memiliki sistem pengendalian mutu yang memadai, dan sistem pengendalian mutu tersebut harus direviu oleh pihak lain yang kompeten (pengendalian mutu ekstern)

\section{3) Kode Etik}

Etika secara umum didefinisikan sebagai nilai-nilai tingkah laku atau aturan-aturan tingkah laku yang diterima dan digunakan oleh suatu golongan tertentu atau individu (Sukamto 1991 dalam Suraida 2005: 118). Definisi etika secara umum adalah "a set of moral principles or value. Prinsip-prinsip etika tersebut (yang dikutip dari The Yosephine Institute for teh Advancement of Ethics) adalah honesty, 
integrity, promise keeping, loyalty, fairness, caring for others, responsible citizenship, pursuit of excellent and accountability (Arrens \& Loebecke 2003).

Etika pemeriksa pada BPK RI mengacu pada Peraturan BPK RI No.2 Tahun 2007 tentang Kode Etik Badan Pemeriksa Keuangan Republik Indonesia.

a) Dimana pasal 2 menyatakan bahwa setiap Anggota BPK dan Pemeriksa wajib: mematuhi peraturan perundang-undangan dan peraturan kedinasan yang berlaku. Mengutamakan kepentingan negara atas kepentingan pribadi atau golongan. Menjunjung tinggi independensi, integritas dan profesionalitas. Menjunjung tinggi martabat, kehormatan, citra dan kredibilitas BPK.

b) Pasal 6 ayat (1) menyatakan bahwa untuk menjamin independensi dalam menjalankan tugas dan wewenangnya, pemeriksa wajib: bersikap netral dan tidak memihak. Menghindari terjadinya benturan kepentingan dalam melaksanakan kewajiban profesionalnya. Menghindarihal-hal yang dapat mempengaruhi independensi. Mempertimbangkan informasi, pandangan dan tanggapan dari pihak yang diperiksa dalam menyusun opini atau laporan pemeriksaan. Bersikap tenang dan mampu mengendalikan diri. Ayat (2) menyatakan bahwa untuk menjamin independensi dalam menjalankan tugas dan wewenangnya, pemeriksa dilarang: merangkap jabatan dalam lingkungan lembaga negara yang lain, badan-badan lain yang mengelola keuangan negara, dan perusahaan swasta nasional atau asing. Menunjukkan sikap dan perilaku yang dapat menyebabkan orang lain meragukan independensinya. Tunduk pada intimidasi atau tekanan orang lain. Membocorkan informasi yang diperolehnya dari auditee. Dipengaruhi oleh prasangka, interpretasi atau kepentingan tertentu, baik kepentingan pribadi pemeriksa sendiri maupun pihak-pihak lainnya yang berkepentingan dengan hasil pemeriksaan.

c) Pasal 7 ayat (1) menyatakan bahwa untuk menjamin integritas dalam menjalankan tugas dan wewenangnya, pemeriksa wajib: bersikap tegas dalam menerapkan prinsip, nilai, dan keputusan. Bersikap tegas untuk mengemukakan dan/ atau melakukan halhal yang menurut pertimbangan dan keyakinannya perlu dilakukan. Bersikap jujur dan terus terang tanpa harus mengorbankan rahasia pihak yang diperiksa. Ayat 
menyatakan untuk menjamin integritas dalam menjalankan tugas dan wewenangnya, pemeriksa dilarang: menerima pemberian dalam bentuk apapun baik langsung maupun tidak langsung yang diduga atau patut diduga dapat mempengaruhi pelaksanaan tugas dan wewenangnya. Menyalahgunakan wewenangnya sebagai pemeriksa guna memperkaya atau menguntungkan diri sendiri atau pihak lain.

d) Pasal 8 ayat (1) menyatakan bahwa untuk menjunjung profesionalisme dalam menjalankan tugas dan wewenangnya, pemeriksa wajib: menerapkan prinsip kehati-hatian, ketelitian dan kecermatan. Menyimpan rahasia negara atau rahasia jabatan pihak yang diperiksa dan hanya mengemukakannya kepada pejabat yang berwenang. Menghindari pemanfaatan rahasia negara yang diketahui karena kedudukan atau jabatannya untuk kepentingan pribadi, golongan, atau pihak lain. Menghidari perbuatan di luar tugas dan wewenangnya. Mempunyai komitmen tinggi untuk bekerja sesuai dengan standar pemeriksa keuangan negara. Memutakhirkan, mengembangkan, dan meningkatkan kemampuan profesionalnya dalam rangka melaksanakan tugas pemeriksaan. Menghormati dan mempercayai serta saling membantu diantara pemeriksa sehingga dapat bekerjasama dengan baik dalam pelaksanaan tugas. Saling berkomunikasi dan mendiskusikan permasalahan yang timbul dalam menjalankan tugas pemeriksaan. Menggunakan sumber daya publik secara efisien, efektif dan ekonomis. Ayat (2) menyatakan untuk menjunjung profesionalisme dalam menjalankan tugas dan wewenangnya, pemeriksa dilarang: menerima tugas yang bukan merupakan kompetensinya. Mengungkapkan informasi yang terdapat dalam proses pemeriksaan kepad pihak- pihak lain, baik lisan maupun tertulis, kecuali untuk kepentingan peraturan perundang-undangan yang berlaku. Mengungkapkan laporan hasil pemeriksaan atau substansi hasil pemeriksaan kepada media massa kecuali atas ijin atau perintah ketua atau wakil ketua atau Anggota BPK. Mendiskusikan pekerjaannya dengan auditee diluar kantor BPK atau kantor auditee.

\section{4) Pengalaman Auditor}

Pengalaman auditor adalah pengalaman dalam melakukan audit 
laporan keuangan baik dari segi lamanya waktu, banyaknya penugasan maupun jenis-jenis pemeriksaan yang pernah ditangani. Alasan yang paling umum dalam mendiagnosis suatu masalah adalah ketidak mampuan menghasilkan dugaan yang tepat. Libby dan Frederick (1990) dalam (Suraida 2005:119) bahwamakin banyak pengalaman auditor makin dapat menghasilkan berbagai macam dugaan dalam menjelaskan temuan audit.

Definisi lain menyebutkan bahwa pengalaman merupakan suatu proses pembelajaran dan pertambahan perkembangan potensi bertingkah laku baik dari pendidikan formal maupun non formal atau bisa diartikan sebagai suatu proses yang membawa seseorang kepada suatu pola tingkah laku yang lebih tinggi. Suatu pembelajaran juga mencakup perubahan yang relatif dari perilaku yang diakibatkan pengalaman, pemahaman dan praktik (Knoers dan Haditono 1999 dalam Asih 2006: 12).

Pengalaman merupakan atribut yang penting bagi auditor, terbukti dengan tingkat kesalahan yang dibuat auditor, auditor yang sudah berpengalaman biasanya lebih dapat mengingat kesalahan atau kekeliruan yang tidak lazim/ wajar dan lebih selektif terhadap informasiinformsi yang relevan dibandingkan dengan auditor yang kurang berpengalaman (Meidawati 2001 dalam Asih 2006: 13). Purnamasari (2005: 15), memberikan kesimpulan bahwa seorang pegawai yang memiliki pengalaman kerja yang tinggi akan memiliki keunggulan dalam beberapa hal diantaranya mendeteksi kesalahan dari penyebab munculnya kesalahan. Berbagai macam pengalaman yang dimiliki individu akan menpengaruhi pelaksanaan suatu tugas. Seseorang yang berpengalaman memiliki cara berpikir yang lebih terperinci, lengkap dan sophisicated dibandingkan seseorang yang belum berpengalaman (Taylor dan Tood 1995 dalam Asih, 2006:13)

Sebagai seorang akuntan yang profesional, harus menjalani pelatihan yang cukup. Pelatihan disini dapat berupa kegiatan -kegiatan seperti seminar, simposium, lokakarya, dan kegiatan penunjang keterampilan yang lain. Selain kegiatan-kegiatan tersebut, pengarahanyang diberikan oleh auditor senior kepada auditor yunior juga bisa dianggap sebagai salah satu bentuk pelatihan karena kegiatan ini dapat meningkatkan kerja auditor. melalui program pelatihan dan praktik-praktik audit yang dilakukan para auditor juga mengalami proses sosialisasi agar dapat menyesuaikan diri dengan 
perubahan situasi yang akan ia temui, struktur pengetahuan auditor yang berhubungan dengan pendeteksian kekeliruan mungkin akan berkembang dengan adanya program pelatihan auditor ataupun dengan bertambahnya pengalaman auditor.

Penelitian oleh Syafina (2009) meneliti tentang Pengaruh Profesionalisme dan Pengalaman Auditor BPK Perwakilan Provinsi Sumatera Utara terhadap tingkat materialitas dalam pemeriksaan laporan keuangan pemerintah. Penelitian Herawaty dan Susanto (2008) meneliti tentang profesionalisme, pengetahuan akuntan publik dalam mendeteksi kekeliruan, etika profesi terhadap pertimbangan tingkat materialitas. Penelitian Suraida (2005) meneliti tentang Uji Model Etika, Kompetensi, Pengalaman Audit dan Resiko Audit terhadap Skeptisisme Profesional Auditor.

\section{5) Perumusan Hipotesis}

H1 : Profesionalisme Auditor memiliki pengaruh terhadap pertimbangan tingkat materialitas.

$\mathrm{H}_{2}$ : Ketaatan terhadap kode etik memiliki pengaruh terhadap Pertimbangan Tingkat Materialitas.

H3 : Pengalaman Auditor memiliki pengaruh terhadap Pertimbangan Tingkat Materialitas.

H4 : Profesionalisme Auditor, Ketaatan Kode Etik, dan Pengalaman Auditor secara simultan memiliki pengaruh terhadap Pertimbangan Tingkat Materialitas.

Penelitian ini merupakan penelitian kausal komparatif, yaitu penelitian yang bertujuan untuk mengetahui kemungkinan adanya hubungan sebab akibat dengan cara tertentu berdasar atas pengamatan terhadap akibat yang ada, kemudian mencari kembali faktor yang diduga menjadi penyebabnya, melalui pengumpulan data dengan melakukan perbandingan diantara data yang terkumpul/diteliti (Sumarni dan Wahyuni 2006:53)

Menurut Sugiyono (2002:72) populasi adalah wilayah generalisasi yang terdiri atas obyek atau subyek yang mempunyai kualitas dan karakteristik tertentu yang ditetapkan oleh peneliti untuk dipelajari kemudian ditarik kesimpulannya. Populasi dalam penelitian ini adalah auditor yang bekerja pada Badan Pemeriksa Keuangan Republik Indonesia. Sampel adalah bagian dari jumlah dan karakteristik yang dimiliki oleh populasi tersebut (Sugiyono 
2002:73) . Sampel dalam penelitian ini adalah seluruh auditor pemerintah yang bekerja pada BPK-RI Perwakilan Provinsi Bengkulu yang bertugas antara Januari sampai dengan Maret 2013.

Penelitian ini menggunakan data primer yang menggambarkan keadaan sebenarnya dari obyek penelitian. Kegiatan ini dilakukan dengan mempelajari secara langsung tentang BPK RI. Data primer berupa kuesioner, yang diberikan langsung kepada responden.

\section{6) Definisi dan Pengukuran Variabel}

a) Materialitas

Variabel dependen dalam penelitian ini Pertimbangan Tingkat Materialitas, yaitu pertimbangan auditor atas besarnya penghilangan atau salah saji informasi akuntansi yang dapat mempengaruhi pertimbangan pihak yang meletakkan kepercayaan terhadap informasi tersebut yang dilihat berdasarkan pengetahuan tentang tingkat materialitas, seberapa penting tingkat materialitas, resiko audit, tingkat materialitas antar pemerintah dan urutan tingkat materialitas dalam rencana audit.

\section{b) Profesionalisme Auditor}

Profesionalisme auditor merupakan sikap dan perilaku auditor dalam menjalankan profesinya dengan kesungguhan dan tanggung jawab agar mencapai kinerja tugas sebagaimana yang diatur oleh organisasi profesi, meliputi pengabdian pada profesi, kewajiban sosial, kemandirian, keyakinan profesi dan hubungan dengan rekan seprofesi.

c) Ketaatan terhdap Kode Etik

Kode Etik adalah nilai-nilai tingkah laku atau aturan-aturan tingkah laku yang diterima dan digunakan oleh organisasi BPK RI yang meliputi Integritas, independensi, dan profesional.

d) Pengalaman Auditor

Pengalaman Auditor adalah pengalaman dalam melakukan audit laporan keuangan baik dari segi lamanya waktu, banyaknya penugasan maupun jenis-jenis pemeriksaan yang pernah ditangani.

\section{e) Pengukuran Variabel Penelitian}

Pertimbangan tingkat materialitas dan profesionalisme auditor dengan indikator yang mengacu pada instrumen penelitian Novanda (2012). Sedangkan kode etik dengan indikator yang mengacu pada instrumen penelitian Putri (2011) dan pengalaman auditor dengan indikator yang mengacu pada instrumen penelitian Khairiah (2009). 
Variabel pertimbangan tingkat materialitas, profesionalisme auditor, dan ketaatan terhadap kode etik diukur dengan skala ordinal menggunakan modifikasi skala likert, yaitu Sangat Setuju (SS) di beri skor 5, Setuju (S) di beri skor 4, Netral (N) di beri skor 3, Tidak Setuju (TS) di beri skor 2 dan Sangat Tidak Setuju (STS) di beri skor 1. Variabel pengalaman auditor diukur dengan skala interval.

\section{Hasil dan Pembahasan}

Berdasarkan hasil uji hipotesis sederhana hanya satu variabel yang mempengaruhi pertimbangan tingkat materialitas dari tiga variabel yang diteliti, namun secara simultan ketiga variabel tersebut mempengaruhi pertimbangan tingkat materialitas.

Hasil penelitian ini menunjukkan tidak ada pengaruh yang signifikan antara profesionalisme auditor dengan pertimbangan dengan tingkat materialitas. Hal ini disebabkan karena entitas LKPD merupakan sektor publik dengan ketentuan pengelolaan yang sama untuk semua entitas maka BPK RI menetapkan nilai risiko pemeriksaan yang dapat diterima (Accepteble Audit Risk) yang sama untuk semua entitas LKPD yaitu sebesar 5\%. Namum demikian, pemeriksa dapat memberikan pertimbangan lain untuk menurunkan besaran AAR dengan pertimbangan faktor-faktor antara lain : kondisi geografis, nilai aset dan anggaran yang tidak di kelola, jumlah satuan kerja (Satker), hasil pemeriksaan sebelumnya, integritas manajemen dan sistem informasi yang digunakan.(panduan pemeriksaan LKPD edisi tahun 2013).

Berdasarkan jawaban responden terhadap pernyataan profesionalisme auditor secara umum responden menjawab setuju $(61,4 \%)$ dan sangat setuju $(23,1 \%)$, namum masih terdapat banyak jawaban responden yang netral $(\mathrm{N})$ pada keyakinan terhadap profesi pada item 11 dimana jawaban responden menunjukkan 24 responden menjawab netral dari 43 responden. Namun pada pernyataan kewajiban sosial item ke 6 sebanyak 32 dari 43 responden menjawab setuju.

Berdasarkan jawaban responden terhadap pernyataan tentang ketaatan terhadap kode etik menunjukkan sebagian besar responden menjawab setuju (58\%) dan sangat setuju $(25,4 \%)$, hal ini menunjukkan bahwa sebagian besar responden setuju untuk menerapkan ketaatan terhadap kode etik dalam melakukan audit. Hal ini juga ditunjukan oleh jawaban responden untuk pernyataan 
independensi item ke 2 dimana sebanyak 32 dari 43 responden menjawab setuju, dan pada pernyataan integritas item ke 6 dimana sebanyak 33 dari 43 responden menjawab setuju.

Berdasarkan jawaban responden terhadap pernyataan tentang pengalaman auditor sebanyak 21 dari 43 responden mengarah pada jawaban 3 yaitu masa kerja 3 s,d 5 tahun, menjadi ketua tim jawaban responden sebanyak 29 dari 43 responden mengarah pada jawaban 1 yaitu belum pernah menjadi ketua tim, menjadi ketua sub tim jawaban responden sebanyak 34 dari 43 responden mengarah pada jawaban 1 yaitu belum pernah menjadi ketua sub tim, jumlah unit kerja yang diaudit dalam LKPD jawaban responden sebanyak 40 dari 43 responden mengarah pada jawaban 5 yaitu lebih dari 4 SKPD. Dengan demikian pengalaman auditor BPK RI Perwakilan Bengkulu masih sangat sedikit dalam hal melakukan audit.

Berdasarkan uji regresi secara simultan, pertimbangan tingkat materialitas suatu laporan keuangan dipengaruhi oleh profesionalisme auditor, ketaatan terhadap kode etik dan pengalaman auditor. namun, pengaruh tersebut hanya sebesar 39,4\% sedangkan sisanya sebesar $60,6 \%$ dipengaruhi oleh faktor lain di luar penelitian ini.

\section{Kesimpulan}

Profesionalisme Auditor di BPK tidak mempunyai pengaruh yang signifikan terhadap pertimbangan tingkat materialitas, pengambilan keputusan dalam menentukan tingkat materialitas dan dipengaruhi oleh faktor lainnya di luar penelitian ini. Pengalaman auditor di BPK tidak mempunyai pengaruh yang signifikan terhadap pertimbangan tingkat materialitas, hal ini disebabkan karena auditor BPK biasanya menggunakan judgement auditor dimana hal ini terjadi jika ditemukan permasalahan tentang tingkat materialitas maka akan dibuat kebijakan untuk menyamakan persepsi. Profesionalisme auditor, ketaatan terhadap kode etik dan pengalaman auditor secara bersamasama mempunyai pengaruh yang signifikan terhadap pertimbangan tingkat materialitas. 
Penenlitian ini bermanfaat bagi pengambil kebijakan pada BPK RI sebagai bahan pertimbangan untuk menentukan pola mutasi yang tepat agar pemerataan auditor yang berpengalaman pada setiap kantor perwakilan sehingga dapat menghasilkan kualitas laporan hasil pemeriksaan yang sama pada setiap kantor perwakilan.

Bagi auditor, perlu meningkatkan pengetahuan tambahan yang dapat membentuk sikap profesionalisme yang dapat mendukung pertimbangan auditor dalam menentukan tingkat materialitas suatu laporan keuangan pemerintah daerah. Dalam melaksanakan tugas pemeriksaan, seorang auditor harus tetap taat terhadap kode etik yang sudah ditetapkan oleh BPK RI, termasuk tidak bertindak menurut keinginan pribadi.

Berdasarkan hasil penelitian pengalaman auditor rata-rata masih sedikit, sehingga perlu ada berbagi pengalaman dengan tim sebelumnya, sehingga pelaksanaan pemeriksaan dapat terencana dengan baik dan dapat memberikan perbaikan kepada pemerintah daerah itu sendiri. Sehingga dapat menambah pengalaman yang akan mendampak pada sikap profesional untuk mengambil keputusan dalam menentukan tingkat materialitas dalam laporan.

Auditor BPK RI Perwakilan Provinsi Bengkulu, memperbanyak pengalaman pemeriksaan dengan tidak hanya pemeriksaan laporan keuangan pemerintah daerah tapi juga pemeriksaan laporan keuangan Badan Usaha Milik Negara/Daerah, Bank Pembangunan Daerah dan Lainnya. Dengan demikian, auditor semakin berpengalaman dalam melakukan audit dan menentukan tingkat risiko audit pada setiap akun, sehingga dapat menentukan tingkat materialitas yang tepat. Untuk penelitian selanjutnya diharapkan bisa menambahkan variabel lain seperti opini tahun sebelumnya, informasi dari media masa, dan risiko terjadinya tindakan kecurangan (Fraud) yang diduga mempengaruhi tingkat pertimbangan materialitas. 


\section{DAFTAR PUSTAKA}

Asih. (2006). Pengaruh Pengalaman Terhadap Peningkatan Keahlian Auditor dalam Bidang Auditing. Skripsi. Tidak Dipublikasikan.

Hastuti, dkk. (2003). Hubungan antara Profesionalisme dengan Pertimbangan Tingkat Materialitas dalam Proses Pengauditan Laporan Keuangan. Prosiding Simposium Nasional Akuntansi. OKtober. Hal 1206-1220

Herawati dan Susanto (2009). Pengaruh Profesionalisme, Pengetahuan mendeteksi kekeliruan dan etika profesi terhadap pertimbangan Tingkat Materialitas Akuntan Publik. Jurnal Akuntansi dan Keuangan Vol. 11 No.1

Ifada dan M. Ja'far. (2005). Pengaruh Sikap Profesionalisme Internal Auditor Terhadap Peranan Internal Auditor dalam Pengungkapan Temuan Audit. Jurnal Bisnis, Manajemen dan Ekonomi. Vol.7 No.3.

Keputusan Badan Pemeriksa Keuangan Republik Indonesia No.05/K/IXIII.2/5/2008 Tentang petunjuk teknis penetapan batas materialitas pemeriksaan keuangan.

Lestari dan Dwi. (2003). Hubungan antara Profesionalisme Auditor dengan Pertimbangan Tingkat Materialitas dalam Proses Pengauditan Laporan Keuangan. Jurnal Bisnis, Manajemen dan Ekonomi. Vol.2 No.1

Martiyani. (2010). Pengaruh Profesionalisme Auditor dan Kualitas Audit terhadap tingkat Materialitas dalam dalam Pemeriksaan Laporan Keuangan. Skripsi. Tidak dipublikasikan. Universitas Pembangunan Nasional'Veteran" Surabaya Jawa Timur.

Mardiasmo. (2001). Pengawasan, pengendalian, dan pemeriksaan kinerja pemerintah dalam pelaksanaan otonomi daerah. Jurnal bisnis dan akuntansi. Sekolah tinggi ilmu ekonomi Trisakti. Jakarta. Edisi Agusutus.

Noveria. (2006). Pengaruh Profesionalisme Auditor Internal terhadap Work Outcome Auditor Internal. Skripsi. Tidak dipublikasikan. 
UNPAD Bandung.

Novanda (2012). Pengaruh profesionalisme auditor, etika profesi dan pengalaman audit terhadap pertimbangan tingkat materialitas. Skripsi. UNY Yogyakarta.

Rifqi Muhammad (2008). Analisis hubungan antara profesionalisme auditor dengan pertimbangan tingkat materialitas dalam proses pengauditan laporan keuangan. Jurnal penelitian dan pengabdian. DPPM UII. YOGYAKARTA.

Santoso. (2000). Mengatasi Berbagai Masalah Statistik dengan SPSS. Jakarta: PT. Gramedia Pustaka Utama.

Sugiyono. (2001). Metode Penelitian Bisnis. Bandung. CV. Alfabeta

Sugiyono. (2002). Statistik Untuk Penelitian. Bandung : CV Alfabeta

Sumarni dan Wahyuni. (2006). Metodologi Penelitian Bisnis. Yogyakarta: Andi Offset.

Suraida. (2005). Uji Model Etika, Kompetensi, Pengalaman Audit dan Resiko Audit Terhadap Skeptisme Profesional Auditor. Jurnal Akuntansi. Th IX/02/Mei.

Syahrir. (2002). Analisis hubungan antara profesionalisme akuntan publik dengan kinerja, kepuasan kerja, komitmen, dan keinginan berpindah. Tesis. FE UGM. Yogyakarta.

Syafina. (2009). Profesionalisme dan Pengalaman auditor BPK Perwakilan Provinsi Sumatera Utara terhadap tingkat materialitas dalam pemeriksaan laporan keuangan pemerintah. Tesis. Tidak dipublikasikan.USU Medan.

Peraturan BPK-RI Nomor 01 Tahun 2007 tentang Standar Pemeriksaan Keuangan Negara. Peraturan BPK-RI Nomor 02 Tahun 2007 tentang Kode Etik Badan Pemeriksa Keuangan Republik Indonesia.

Purnamasari. (2005). Pengaruh pengalaman kerja terhadap hubungan pertisipasi dengan efektivitas sistem informasi. Jurnal riset 
akuntansi keuangan. Vol.1 No.3.

Wilopo (2001). Faktor-faktor yang menentukan kualitas audit pada sektor publik atau pemerintah. Ventura. Volume 4. No.1, Juni. Hal. 27-32.

Yanuar (2008). Pengaruh profesionalisme auditor dan pengalaman auditor terhadap tingkat materialitas dalam pemeriksaan laporan keuangan (studi kasus pada auditor BPK Yogyakarta) skripsi. Tidak dipublikasikan. 